Seminário de Pesquisa

Programa de Pós-Graduação

Design FAU USP

\title{
Como o silêncio se manifesta no livro-álbum: entrevistas e análise de obras
}

\author{
Daniela Gutfreund, Clice de Toledo Sanjar Mazzilli
}

\author{
em branco; virada da página; livro-álbum
}

O silêncio contribui para a narrativa nos livros-álbum? Esta pesquisa tem intenção de investigar possíveis contribuições do silêncio na construção da narrativa na produção de livros-álbum contemporâneos. Por meio da análise de uma seleção de obras, em que há uma relevante presença do silêncio no tecer da narrativa, seja pela presença do que está em branco, seja no momento do virar da página, evidenciando, assim, elementos que potencializam a leitura

Curso

Mestrado

\section{Linha de Pesquisa}

Design: Processos e Linguagens

\section{Daniela Gutfreund}

Graduada em Pedagogia (PUC$\mathrm{SP})$ tem mestrado em Literatura Contemporânea Inglesa (Goldsmith's College, University of London), com especialização em tradução (City University-Londres). Hoje colabora com a editora Livros da Matriz e é gestora do Lugar de Ler. É autora de Olha lá a Ana! (MOVpalavras).

e-mail: danigutfreund@usp.br Lattes: http://lattes.cnpq. $\mathrm{br} / 7868618547107271$

Orcid: https://orcid.org/00000002-7565-2877

\section{Clice de Toledo Sanjar Mazzilli}

Graduada em Arquitetura e Urbanismo (1984), com mestrado (1993), doutorado (2003) e livredocência (2015) na FAU-USP na área de Programação Visual. Leciona no Departamento de Projeto da FAU-USP e atualmente coordena o Programa de Pósgraduação em Design e o Laboratório de Programação Gráfica (LPG).

e-mail: clice@usp.br

Lattes: http://lattes.cnpq. $\mathrm{br} / 9635315172253349$

Orcid: https://orcid.org/00000002-6903-9099 através de uma compreensão mais profunda da própria linguagem. Este estudo está dividido em duas seções principais intrinsecamente relacionadas: um glossário do livro-álbum que define os elementos formais, gráficos, sintáticos e materiais específicos dessa linguagem, potencializando a compreensão de sua gramática; e a análise aprofundada do branco e do virar da página no corpus, em que tais elementos narrativos se configuram de maneira específica e determinante para a compreensão da linguagem. O glossário resulta da sistematização do levantamento e revisão bibliográficos. A análise crítica dos aspectos formais e elementos gráficos e materiais do corpus, com enfoque no silêncio, especificamente representado pela presença do branco e no ato de virar de páginas, tem como subsídio teórico a fenomenologia, a crítica literária, e a sintaxe da linguagem visual. Esta análise está sendo realizada em conjunto com as entrevistas com os 5 autores, cujas obras estão sendo investigadas. O corpus é composto por: O caminhão e A visita, de Lúcia Hiratsuka; Lá e aqui e Lulu e o urso, de Carolina Moreyra e Odilon Moraes; Linea 135, de Germano Zullo e Albertine; Meu tio chega amanhã, de Sebastián Camargo Santana. 


\title{
How silence manifests itself in picturebooks: interviews and analysis of works
}

\author{
Daniela Gutfreund, Clice de Toledo Sanjar Mazzilli
}

\author{
blank, turn of page, picturebook
}

Silence contributes to narratives in picturebooks? This study aims to investigate possible contributions of silence to build narratives in contemporary picturebooks. The analysis of the selected books, in which it is possible to observe an important presence of silence intertwining narratives, either by what is left blank or in the act of turning pages, and in doing so, making evident elements that enrich reading through a deeper understanding of the language itself. This study is divided into two main sections, which are intrinsically connected: a glossary of picturebook terms, defining its formal, graphic, syntactic and material elements, potentializing the comprehension of its grammar; and the analysis of what is blank and the turn of the page in the corpus, in which these narrative elements are set in an specific manner and is fundamental to the comprehension of such language. The glossary is a result of the systematization of the bibliographic review, including critical analysis of formal aspects and graphic and material elements of the corpus, with focus on silence, represented specifically on what is blank and in the act of turning pages, having as a theoretical benchmark the phenomenology, the literary critics, and visual language sintaxis. Interviews with authors of the works that are being analysed were conducted. They are: Lúcia Hiratsuka, Carolina Moreyra e Odilon Moraes, Albertine and Sebastián Camargo Santana. The corpus is composed by: O caminhão and A visita, de Lúcia Hiratsuka; Lá e aqui and Lulu e o urso, de Carolina Moreyra e Odilon Moraes; Linea 135, de Germano Zullo e Albertine; Meu tio chega amanhã, de Sebastián Camargo Santana.

\section{Referências | References}

BADER, B. 1976. American Picturebooks from Noah's Ark to the Beast Within. Nova York: Macmillan Publishing and Co.

DIDI-HUBERMAN, G. 1998. O que vemos, o que nos olha. São Paulo: Editora 34. DONIS, A. D. 2015. A sintaxe da linguagem visual. São Paulo: Martins Fontes. LE BRETON, D. 2001. Del silencio. Madri: Sequitur. MELOT, M. 2011. Livro,. São Paulo: Ateliê Editorial.

\section{Clice de Toledo Sanjar Mazzilli}

Bacharel in Architecture and Urbanism (1984), with Masters (1993), Doctorate (2003) e PhD (2015) in FAU-USP in the Visual Programme area. Teaches at the Department of Design in FAU USP and today coordinates the Postgraduate program in Design and the Graphich Programme Lab (LPG).

e-mail: clice@usp.br

Lattes: http://lattes.cnpq. $\mathrm{br} / 9635315172253349$

Orcid: https://orcid.org/00000002-6903-9099 